\begin{tabular}{|c|c|}
\hline & $\begin{array}{l}\text { International Journal of Trend in Scientific } \\
\text { Research and Development (IJTSRD) }\end{array}$ \\
\hline 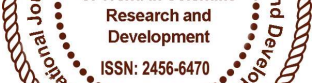 & International Open Access Journal \\
\hline 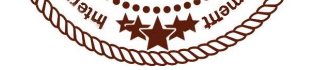 & ISSN No: 2456 - 6470 | www.ijtsrd.com | Volume - 2 | Issue - 2 \\
\hline
\end{tabular}

\title{
The Regional Disparities in Literacy Rate and Gender Gap among the Indian Scheduled Tribes
}

\author{
Kabita Auddya \\ Faculty in Geography, Magrahat College, West Bengal, India
}

\begin{abstract}
In India, there are more than 533 tribal communities scattered all over the states. Tribal communities live, in various ecological and geo-climatic conditions ranging from plains and forests to hills and inaccessible areas. Because of this geographical isolation, they are often excluded from development process. Tribal groups are at different stages of social, economic and educational development. The present paper makes an attempt to analyse the gender gap in literacy rate among the Scheduled Castes population of India.
\end{abstract}

Keywords: Gender Gap, Literacy, Regional Disparity, Scheduled Tribes

\section{INTRODUCTION}

In India one of the most deep rooted forms of inequality is gender disparity. Gender disparity in literacy and education is one important dimension of gender inequality and is contingent on other factors of gender discrimination, which have been inherited form the traditional society. Education has been recognized as critical in the Directive Principle of State Policy of the Constitution of India, where it is stated: "The State shall endeavor to provide, within a period of ten years from the commencement of this Constitution, free and compulsory education for all children until they complete the age of 14 years". While the country has made significant progress in literacy achievement since the Constitution came into effect, it is still considerably short of its goal of universal education. Notwithstanding the special emphasis on the universalities of education in the educational policy statements of 1986 and the revised version of 1992, and the genuine efforts and intention of the government, universal education, the girls are lagging behind the boys.

Education forms an important component in the overall development of individuals, enabling them to greater awareness, better comprehension of their social, political and cultural environment and facilitating in the improvement of their socioeconomic conditions. These hold true in the case of the Scheduled Tribes in India. Scheduled tribes are one of the most disadvantaged groups in the country. Literacy level varies across the states among them. The tribal population of the country, as per 2011 census is 104.28 million, constituting 8.6 per cent of the country's population. It is worth to mention here that there is a great variation between the varieties/types of the Scheduled Tribes in one state/UT to another. They are multicultural and multiracial groups. More than half of them are concentrated in Madhya Pradesh, Chhattisgarh, Maharashtra, Orissa, Jharkhand and Gujarat. Almost 90 per cent of them reside in rural areas particularly in difficult terrains, interiors of forests or remote hilly areas which are normally less accessible to the mainstream population. This in fact has lead to the socio-economic backwardness of the community. As per 2011 census, country's largest tribal population is found in Madhya Pradesh (14.6 \%) with 46 tribes (main and sub-tribes). The second largest number of tribal population is enumerated in Maharashtra (10.08\%) immediately followed by Orissa (9.2\%). The states, which have more inhospitable geographical area, registered more tribal population. 
Two states - Haryana and Punjab and three UTs Delhi, Chandigarh, Puducherry, do not have any single notified tribe. The detailed data released by the Census 2011, form the basis of present discussion.

\section{Data and Methodology}

The present study has been made here to highlight the regional variations in literacy pattern and gender gap in literacy rate among the Scheduled Tribes population of India using secondary data released by the Census 2011. The analysis is by and large based on state level data which is used to investigate the regional disparities in literacy of tribal population in India.

\section{Objectives}

- To analyse the inter-state disparity in literacy rates of Scheduled tribes.

- To study the male-female literacy gap within the Scheduled Tribes.

\section{Regional Disparity in Literacy Pattern}

Literacy is one of the important social aspects. According to census 2011, a person aged seven and above who both can read write and understanding of any language is treated as literate. It is one of the most important indicators of human development. Literacy is a qualitative indicator of social awakening and cultural advancement of the inhabitants in a geographical unit, whereas a change in literacy reflects the socio-economic and cultural transformation of any society. Keeping in view the significance of the literacy, the United Nations Development Programmed (UNDP) has included this in the criterion to determine the Human Development Index (HDI).

TABLE 1: Literacy Rates by Sex of All Castes and Scheduled Tribe Population in India, 2011

\begin{tabular}{|l|c|c|c|c|c|c|}
\hline \multirow{2}{*}{ States/UTs } & \multicolumn{3}{|c|}{ All Castes Total Population } & \multicolumn{3}{c|}{ STs Total Population } \\
\cline { 2 - 7 } & Persons & Males & Females & Persons & Males & Females \\
\hline 1. Jammu \& Kashmir & 68.74 & 78.26 & 58.01 & 50.6 & 60.6 & 39.7 \\
\hline 2. Himachal Pradesh & 83.78 & 90.83 & 76.60 & 73.6 & 83.2 & 64.2 \\
\hline 3. Punjab & 76.68 & 81.48 & 71.34 & Nil & Nil & Nil \\
\hline 4. Chandigarh & 71.04 & 81.45 & 81.38 & Nil & Nil & Nil \\
\hline 5. Uttarakhand & 69.72 & 79.24 & 70.70 & 73.9 & 83.6 & 63.9 \\
\hline 6. Haryana & 76.64 & 85.38 & 66.77 & Nil & Nil & Nil \\
\hline 7. Delhi & 86.34 & 91.03 & 80.93 & Nil & Nil & Nil \\
\hline 8. Rajasthan & 67.06 & 80.50 & 52.66 & 52.8 & 67.6 & 37.3 \\
\hline 9. Uttar Pradesh & 69.72 & 79.24 & 59.26 & 55.7 & 67.1 & 43.7 \\
\hline 10. Bihar & 63.82 & 73.39 & 53.33 & 51.1 & 61.3 & 40.4 \\
\hline 11. Sikkim & 82.20 & 87.23 & 76.43 & 79.7 & 85.0 & 74.3 \\
\hline 12. Arunachal Pradesh & 66.95 & 73.69 & 59.57 & 64.6 & 71.5 & 58.6 \\
\hline 13. Nagaland & 80.11 & 83.29 & 76.69 & 80.0 & 83.1 & 76.9 \\
\hline 14. Manipur & 70.63 & 86.49 & 73.17 & 72.6 & 77.3 & 67.8 \\
\hline 15. Mizoram & 91.58 & 93.72 & 89.40 & 91.5 & 93.6 & 98.5 \\
\hline 16. Tripura & 87.75 & 92.18 & 83.15 & 79.1 & 86.4 & 71.6 \\
\hline 17. Meghalaya & 75.48 & 77.17 & 73.78 & 74.5 & 75.5 & 73.5 \\
\hline 18. Assam & 73.45 & 78.81 & 67.27 & 72.1 & 79.0 & 65.1 \\
\hline 19. West Bengal & 77.08 & 82.67 & 71.16 & 57.9 & 68.2 & 47.7 \\
\hline 20. Jharkhand & 67.63 & 78.45 & 56.21 & 57.1 & 68.2 & 46.2 \\
\hline 21. Orissa & 73.45 & 82.40 & 64.36 & 52.2 & 63.7 & 41.2 \\
\hline 22. Chhattisgarh & 71.04 & 90.54 & 60.59 & 59.1 & 69.7 & 48.8 \\
\hline 23. Madhya Pradesh & 70.63 & 80.53 & 60.02 & 50.6 & 59.6 & 41.5 \\
\hline 24. Gujarat & 79.31 & 87.23 & 70.73 & 62.5 & 71.7 & 53.2 \\
\hline
\end{tabular}


International Journal of Trend in Scientific Research and Development (IJTSRD) ISSN: 2456-6470

\begin{tabular}{|l|c|c|c|c|c|c|}
\hline 25. Daman \& Diu & 87.07 & 91.48 & 79.59 & 78.8 & 86.2 & 71.2 \\
\hline 26. Dadra \& Nagar Haveli & 77.65 & 86.46 & 65.93 & 61.9 & 73.6 & 50.3 \\
\hline 27. Maharashtra & 82.91 & 89.82 & 75.48 & 65.7 & 74.3 & 57.0 \\
\hline 28. Andhra Pradesh & 67.66 & 75.56 & 59.74 & 49.2 & 58.3 & 40.1 \\
\hline 29. Karnataka & 75.60 & 82.85 & 68.13 & 62.1 & 71.1 & 53.0 \\
\hline 30. Goa & 87.40 & 92.81 & 81.84 & 79.1 & 87.2 & 71.5 \\
\hline 31. Lakshadweep & 92.28 & 96.11 & 88.25 & 91.7 & 95.7 & 87.8 \\
\hline 32. Kerala & 93.91 & 96.02 & 91.98 & 75.8 & 80.8 & 71.1 \\
\hline 33. Tamil Nadu & 80.33 & 86.81 & 73.86 & 54.3 & 61.8 & 46.8 \\
\hline 34. Puducherry & 86.55 & 92.12 & 81.22 & Nil & Nil & Nil \\
\hline 35. Andaman \& Nicobar & 86.27 & 90.11 & 81.84 & 75.6 & 80.9 & 69.9 \\
\hline \multicolumn{1}{|c|}{ INDIA } & 74.04 & 82.14 & 65.46 & 59.0 & 68.5 & 49.4 \\
\hline
\end{tabular}

Source: Census of India 2011

Table 1 shows the literacy rates by sex of all castes and tribal population of India. As per Census 2011 Indian tribal population has registered only 59.0 per cent literacy which is much lower than the literacy of all castes total population at national level (74.04\%). Highest literacy rate among scheduled tribes population is in Lakshadweep $(91.7 \%)$ and lowest is in Andhra Pradesh (49.2\%).

In total, 40 per cent states have registered less literacy from the national average while 60 per cent have recorded high literacy than the country average. The economically backward states reveals low level of level of literacy rates due to the lack of infrastructural facilities of education. In tribal literacy, the first rank holder state in India is Lakshadweep where the various educational plans have been launched by the Christians since colonial period. The highest proportion of male tribal literates has been registered in Lakshadweep $(95.7 \%)$ followed by Mizoram (93.6\%). Likewise, the lowest proportion of male tribal literates was recorded in Andhra Pradesh $(58.3 \%)$ which is much lower than the national average (68.5\%). About 57.14 per cent states have registered the high male literacy than the national average $(68.5 \%)$. Table 1 shows the states wise female literacy of tribal and all castes population with national average. Mizoram leads with 89.5 per cent female literates in all the states followed by Lakshadweep (87.8\%) and Nagaland (76.9\%). Average tribal female literacy of India is registered as only 49.4 per cent which is too less than the all castes female literacy $(65.46 \%)$. Rajasthan has least proportion of female literates $(37.3 \%)$ followed by Jammu and Kashmir (39.7\%). In 2011 census, 40 per cent states have lower in terms of total, males and females literacy than the national averages (Table 1). Female literacy is one of the most important indicators of socio-economic and infrastructural development.

Table 2-4 give the spatial distribution of states by the different ranges and categories of all castes and tribal literacy rates for persons, males and females of India as a whole. In Andhra Pradesh and Jammu and Kashmir, total literacy rates are below 50 per cent which can be recognized as a region with low level of literacy. This literacy region covers 6.67 per cent states. The moderate level (50.01-60.00\%) of literacy region covers 30 Per cent states. These are Orissa, Chhattisgarh, Madhya Pradesh, Tamilnadu, Rajasthan, Uttar Pradesh, Bihar, West Bengal and Jharkhand. There are 16.67 Per cent states of India with total tribal literacy rates between 60.01 and 70.0 per cent and can be termed as moderately high level literacy zone. These are Gujarat, Dadra and Nagar Haveli, Maharashtra, Karnataka, and Andhra Pradesh. About 36.66 per cent states - Daman and Diu, Goa, Kerala, Andaman and Nicobar Island, Himachal Pradesh, Uttarakhand, Sikkim, Manipur, Tripura, Meghalaya, Assam have reported high literacy rates (70.01 $80.00 \%$ ). Only 10 per cent states of India are in the zone of very high level of literacy rates above 80 Per cent - these are Lakshadweep, Mizoram and Nagaland (Table 2). 
International Journal of Trend in Scientific Research and Development (IJTSRD) ISSN: 2456-6470

TABLE 2: Distribution of States/UTs by Ranges of Literacy Rates (Persons) in India, 2011

\begin{tabular}{|c|c|c|c|c|c|c|}
\hline \multirow[t]{2}{*}{$\begin{array}{l}\text { Zone/ } \\
\text { Region }\end{array}$} & \multirow[t]{2}{*}{$\begin{array}{l}\text { Ranges of } \\
\text { Literacy }\end{array}$} & \multicolumn{2}{|c|}{$\begin{array}{l}\text { All Castes } \\
\text { Population }\end{array}$} & \multicolumn{2}{|c|}{ S.T Population } & \multirow[t]{2}{*}{ States/UTs } \\
\hline & & (No.) & $(\%)$ & (No.) & $(\%)$ & \\
\hline Low & $<50.00$ & Nil & Nil & 2 & 6.67 & Andhra Pradesh, Jammu \& Kashmir \\
\hline Moderate & $50.01-60.00$ & Nil & Nil & 9 & 30.00 & $\begin{array}{l}\text { Orissa, Chhattisgarh, Madhya Pradesh, } \\
\text { Tamil Nadu, Rajasthan, Uttar Pradesh, } \\
\text { Bihar, West Bengal, Jharkhand. }\end{array}$ \\
\hline $\begin{array}{l}\text { Moderate } \\
\text { High }\end{array}$ & $60.01-70.00$ & 8 & 22.86 & 5 & 16.67 & $\begin{array}{c}\text { Gujarat, Daman \& Diu, Maharashtra, } \\
\text { Karnataka, Arunachal Pradesh }\end{array}$ \\
\hline High & $70.01-80.00$ & 13 & 37.14 & 11 & 36.66 & $\begin{array}{l}\text { Dadra \& Nagar Haveli, Goa, Kerala, } \\
\text { Andaman and Nicobar, Himachal } \\
\text { Pradesh, Uttarakhand, Sikkim, Manipur, } \\
\text { Tripura, Meghalaya, Assam. }\end{array}$ \\
\hline Very High & $>80.01$ & 14 & 40.00 & 3 & 10.00 & Lakshadweep, Mizoram, Nagaland \\
\hline Total & & 35 & 100.00 & 30 & 100.00 & \\
\hline
\end{tabular}

Source: Census of India, 2011

TABLE 3: Distribution of States/UTs by Ranges of Literacy Rates (Males) in India, 2011

\begin{tabular}{|c|c|c|c|c|c|c|}
\hline \multirow[t]{2}{*}{$\begin{array}{l}\text { Zone/ } \\
\text { Region }\end{array}$} & \multirow[t]{2}{*}{$\begin{array}{l}\text { Ranges of } \\
\text { Literacy }\end{array}$} & \multicolumn{2}{|c|}{$\begin{array}{l}\text { All Castes } \\
\text { Population }\end{array}$} & \multicolumn{2}{|c|}{ S.T Population } & \multirow[t]{2}{*}{ States/UTs } \\
\hline & & (No.) & $(\%)$ & (No.) & $(\%)$ & \\
\hline Low & $<50.00$ & Nil & Nil & $\mathrm{Nil}$ & Nil & Nil \\
\hline Moderate & $50.01-60.00$ & Nil & Nil & $\mathrm{nd}^{3} \mathrm{ir}$ & 10.00 & $\begin{array}{c}\text { Affindhra Pradesh, Madhya Pradesh, } \\
\text { Jammu \& Kashmir, }\end{array}$ \\
\hline $\begin{array}{c}\text { Moderate } \\
\text { High }\end{array}$ & $60.01-70.00$ & Nil & Nil & S8all & 26.6710 & $\begin{array}{c}\text { Tamilnadu, Chhattisgarh, Orissa, } \\
\text { Rajasthan, Uttar Pradesh, Bihar, West } \\
\text { Bengal, Jharkhand }\end{array}$ \\
\hline High & $70.01-80.00$ & 9 & & 8 & 26.67 & $\begin{array}{c}\text { Karnataka, Manipur, Dadra \& Nagar } \\
\text { Haveli, Gujarat, Arunachal Pradesh, } \\
\text { Manipur, Meghalaya, Assam }\end{array}$ \\
\hline Very High & $>80.01$ & 26 & 74.28 & 78 & 36.66 & $\begin{array}{c}\text { Andaman \& Nicobar, Kerala, } \\
\text { Lakshadweep, Goa, Daman \& Diu, } \\
\text { Himachal Pradesh, Uttaranchal, Sikkim, } \\
\text { Nagaland, Mizoram, Tripura }\end{array}$ \\
\hline Total & & 35 & 100.00 & 30 & 100.00 & 3 \\
\hline
\end{tabular}

Source: Census of India, 2011.

Distribution of states by different ranges of male literacy is presented in Table 3 . There is no state in the country with male literacy below 50 per cent, termed as low literacy region while 10 per cent states (Andhra Pradesh, Madhya Pradesh and Jammu \& Kashmir) are found in the region of moderate literacy level, which ranges between 50.01 and 60.00 per cent. Moderately high and high levels of literacy, i.e., (60.01-70.00) percent and above (70.01-80.00) per cent both have recorded 26.67 per cent states/UTs individually. About 36.66 per cent states/UTs- Andaman and Nicobar, Kerala, Lakshadweep, Goa, Daman and Diu, Himachal Pradesh, Uttarakhand, Sikkim, Nagaland, Mizoram, Tripura fall in very high (above 80\%) level of male literacy region (Table 3). 
International Journal of Trend in Scientific Research and Development (IJTSRD) ISSN: 2456-6470

TABLE 4: Distribution of States/UTs by Ranges of Literacy Rates (Females) in India, 2011

\begin{tabular}{|c|c|c|c|c|c|c|}
\hline \multirow[t]{2}{*}{$\begin{array}{l}\text { Zone/ } \\
\text { Region }\end{array}$} & \multirow[t]{2}{*}{$\begin{array}{l}\text { Ranges of } \\
\text { Literacy }\end{array}$} & \multicolumn{2}{|c|}{$\begin{array}{l}\text { All Castes } \\
\text { Population }\end{array}$} & \multicolumn{2}{|c|}{ S.T Population } & \multirow[t]{2}{*}{ States/UTs } \\
\hline & & (No.) & $(\%)$ & (No.) & $(\%)$ & \\
\hline Very Low & $<40.00$ & Nil & Nil & 2 & 6.67 & Rajasthan, Jammu \& Kashmir \\
\hline Low & $40.01-50.00$ & Nil & Nil & 10 & 33.33 & $\begin{array}{l}\text { Tamilnadu, Andhra Pradesh, Dadra \& } \\
\text { Nagar Haveli, Madhya Pradesh, } \\
\text { Chhattisgarh, Orissa, Uttar Pradesh, } \\
\text { Bihar, West Bengal, Jharkhand }\end{array}$ \\
\hline Moderate & $50.01-60.00$ & 7 & 20.00 & 4 & 13.33 & $\begin{array}{c}\text { Karnataka, Maharashtra, Gujarat, } \\
\text { Arunachal Pradesh }\end{array}$ \\
\hline $\begin{array}{c}\text { Moderate } \\
\text { High }\end{array}$ & $60.01-70.00$ & 7 & 20.00 & 6 & 20.00 & $\begin{array}{l}\text { Assam, Manipur, Uttarakhand, Himachal } \\
\text { Pradesh, Goa, Andaman \& Nicobar }\end{array}$ \\
\hline High & $70.01-80.00$ & 12 & 34.29 & 6 & 20.00 & $\begin{array}{l}\text { Kerala, Daman \& Diu, Sikkim, } \\
\text { Nagaland, Tripura, Meghalaya }\end{array}$ \\
\hline Very High & $>80.01$ & 9 & 25.71 & 2 & 6.67 & Lakshadweep, Mizoram \\
\hline Total & & 35 & 100.00 & 30 & 100.00 & \\
\hline
\end{tabular}

Distribution of states by different ranges of female literacy is presented in Table 4. There are only two states (Rajasthan and Jammu \& Kashmir) in the country with female literacy below 40 per cent, termed as very low literacy region while 33.33 per cent states (Tamilnadu, Andhra Pradesh, Dadra \& Nagar Haveli, Madhya Pradesh, Chhattisgarh, Orissa, Uttar Pradesh, Bihar, West Bengal \& Jharkhand) are found in the region of low literacy level, this ranges between 40.01 and 50.00 per cent. Only 13.33 per cent and 20 per cent states of the nation have recorded respectively moderate and moderately high level of literacy, i.e., 50.01-60.00 per cent and 60.01-70.00 per cent. Out of total 30 states, 20 per cent states (Kerala, Daman \& Diu, Sikkim, Nagaland, Tripura, Meghalaya) are in the group of high region (70.01-80.00) while only two states, Lakshadweep and Mizoram are in the region of very high level (above 80.01 per cent) of female literacy.

It is observed that there are contiguous patches of states with low literacy rates in the tribal population of the country. The states/UTs situated in the relatively more rugged topography and adverse climate have also recorded very low literacy rates while states having high literacy associated with comparatively high level of urbanization and high proportion of population in secondary and tertiary jobs. There has been a considerable progress in tribal population including scheduled tribes of the country in the literacy rates during the decade of 2001-2011. There is an urgent need to improve the quality of education than the quantity of literate.

\section{Gender Gap in Literacy Rates}

Table 5 depicts that the states having more literacy reflect less gap between male and female literacy. On an average 19.1 percent point's gap between male and female literacy of the total tribal population in the country has been recorded in 2011 Census which is slightly higher than the literacy of all castes population. Malefemale gap in literacy rate decreased from 24.4 percentage points in 2001 to19.1 percentage points in 2011 for Scheduled Tribes and for the total population, it declined from 21.6 percentage points in 2001 to 16.68 percentage points in 2011. The gap between male and female literacy rate varies from minimum 2.0 per cent in Meghalaya followed by Mizoram (4.1\%) and Nagaland (6.2\%) to maximum 30.3 per cent in Rajasthan. 
TABLE 5. Gaps in Male Female - Literacy Rates in India, 2011

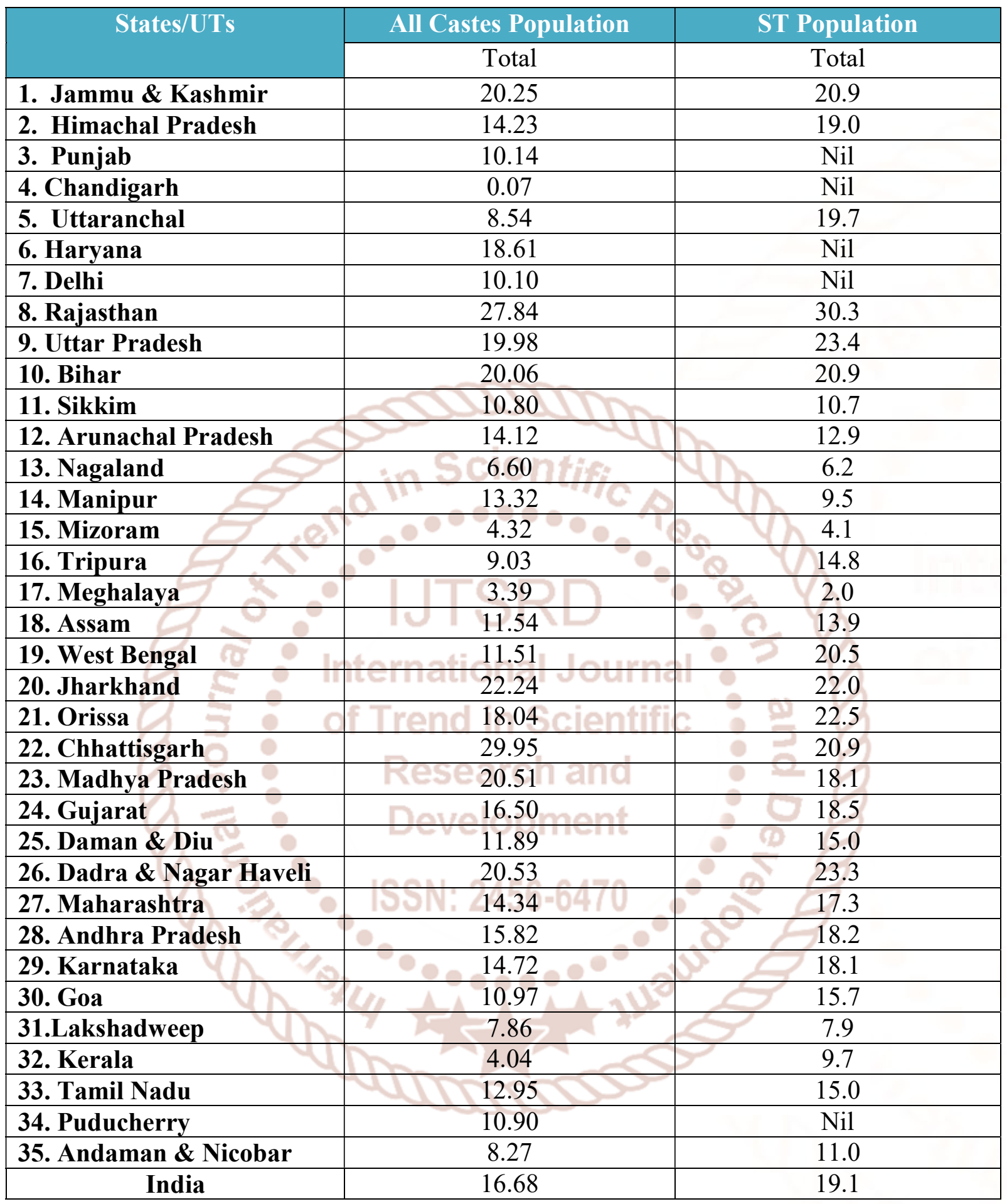

Source: Census of India, 2011. 
International Journal of Trend in Scientific Research and Development (IJTSRD) ISSN: 2456-6470

TABLE 6: Distribution of States/UTs by Ranges of Male-Female Gap in Literacy Rates in India, 2011

\begin{tabular}{|c|c|c|c|c|c|c|}
\hline \multirow[t]{2}{*}{$\begin{array}{l}\text { Zone/ } \\
\text { Region }\end{array}$} & \multirow{2}{*}{$\begin{array}{l}\text { Ranges } \\
\text { of Gap } \\
\text { in } \\
\text { Literacy }\end{array}$} & \multicolumn{2}{|c|}{$\begin{array}{l}\text { All Castes } \\
\text { Population }\end{array}$} & \multicolumn{2}{|c|}{ S.T Population } & \multirow[t]{2}{*}{ States/UTs } \\
\hline & & (No) & $(\%)$ & (No) & $(\%)$ & \\
\hline Very Low & $<10.00$ & 9 & 25.71 & 6 & 20.00 & $\begin{array}{l}\text { Nagaland, Manipur, Mizoram, } \\
\text { Meghalaya, Lakshadweep, Kerala }\end{array}$ \\
\hline Low & $\begin{array}{l}10.01- \\
15.00\end{array}$ & 14 & 40.00 & 7 & 23.33 & $\begin{array}{l}\text { Sikkim, Arunachal Pradesh, Tripura, } \\
\text { Assam, Daman \& Diu, Tamilnadu, } \\
\text { Andaman \& Nicobar. }\end{array}$ \\
\hline Moderate & $\begin{array}{l}15.01- \\
20.00\end{array}$ & 5 & 14.29 & 8 & 26.67 & $\begin{array}{l}\text { Himachal Pradesh, Uttarakhand, } \\
\text { Madhya Pradesh, Gujarat, Maharashtra, } \\
\text { Andhra Pradesh, Karnataka, Goa }\end{array}$ \\
\hline $\begin{array}{c}\text { Moderate } \\
\text { High }\end{array}$ & $\begin{array}{l}20.01- \\
25.00\end{array}$ & 5 & 11 & & 26.67 & $\begin{array}{l}\text { Jammu \& Kashmir, Uttar Pradesh, } \\
\text { Bihar, West Bengal, Jharkhand, Orissa, } \\
\text { Chhattisgarh, Dadra \& Nagar Haveli. }\end{array}$ \\
\hline High & $\begin{array}{c}25.01- \\
30.00 \\
\end{array}$ & & 5.72 & Nil & Nil & Nil \\
\hline Very High & $>30.01$ & Nil & Nil & 1 & 3.33 & Rajasthan \\
\hline Total & 6 & 35 & 100.00 & 30 & 100.00 & 29 \\
\hline
\end{tabular}

Source: Census of India, 2011.

Table 6 gives the distribution of states by the ranges of male- female literacy gap. Rajasthan is only state in the country which have more than 30 per cent malefemale literacy gap among Scheduled Tribe population. About 20 per cent states have less than 10 per cent gap in male- female literacy. These are Nagaland, Manipur, Mizoram, Meghalaya, Lakshadweep and Kerala. Both low (10.01\%-15.01\%) and moderate $(15.01 \%-20.00 \%)$ ranges and of gap in literacy among Scheduled tribes cover 23.33 per cent and 26.67 per cent states respectively. There are 26.27 per cent states of India - Himachal Pradesh, Uttarakhand, Madhya Pradesh, Gujarat, Maharashtra, Andhra Pradesh, Karnataka and Goa. There is no state in high level zone $(25.01 \%-30.00 \%)$ of male- female literacy gap. It is a good sign of development in malefemale literacy gap among Scheduled tribes in our country.

\section{Conclusion}

The tribal community and their habitats constitute very significant parts of backward regions of the country. It is observed that there are contiguous patches of states with low literacy rates in the tribal population of the country. The states with high level of total, male and female literacy have registered fewer gaps between male and female literacy. The study indicated that the Scheduled Tribes lags much behind the mainstream population with respect to literacy and educational attainments. The wide literacy gap between total population and STs continues even after six decades of Indian Independence. The important reason for the low level of education among tribes is their peculiar nature of habitations. Lack of sufficient educational institutions in tribal areas, poverty, and lack of nutritional and healthcare programmes are some of the important problems causing the situation. Besides, low literacy, poor enrolment at schools and high dropouts from schools are also significant among them. Moreover, the educational attainment of Scheduled Tribes also remains poor compared to that of other social groups. All these indicate a need of inclusive literacy campaigns in tribal areas of the country. The study therefore concludes that the plans for the development of tribal population should be launched at the grassroot level. Educational and infrastructural facilities should be provided in the tribal areas as priority level. There is an urgent need of political will to conserve the ecological environment, which is essential for the survival of tribal population in this country. 


\section{References}

1) Census of India (2011), Ministry of Home Affairs, Government of India.

2) Handbook on Social Welfare Statistics, (January 2016), Government of India, Ministry of Social
Justice and Empowerment, Statistical Division, New Delhi.

3) Statistical profile of Scheduled Tribes in India, (2013), Ministry of Tribal Affairs Statistical Division, Government of India.

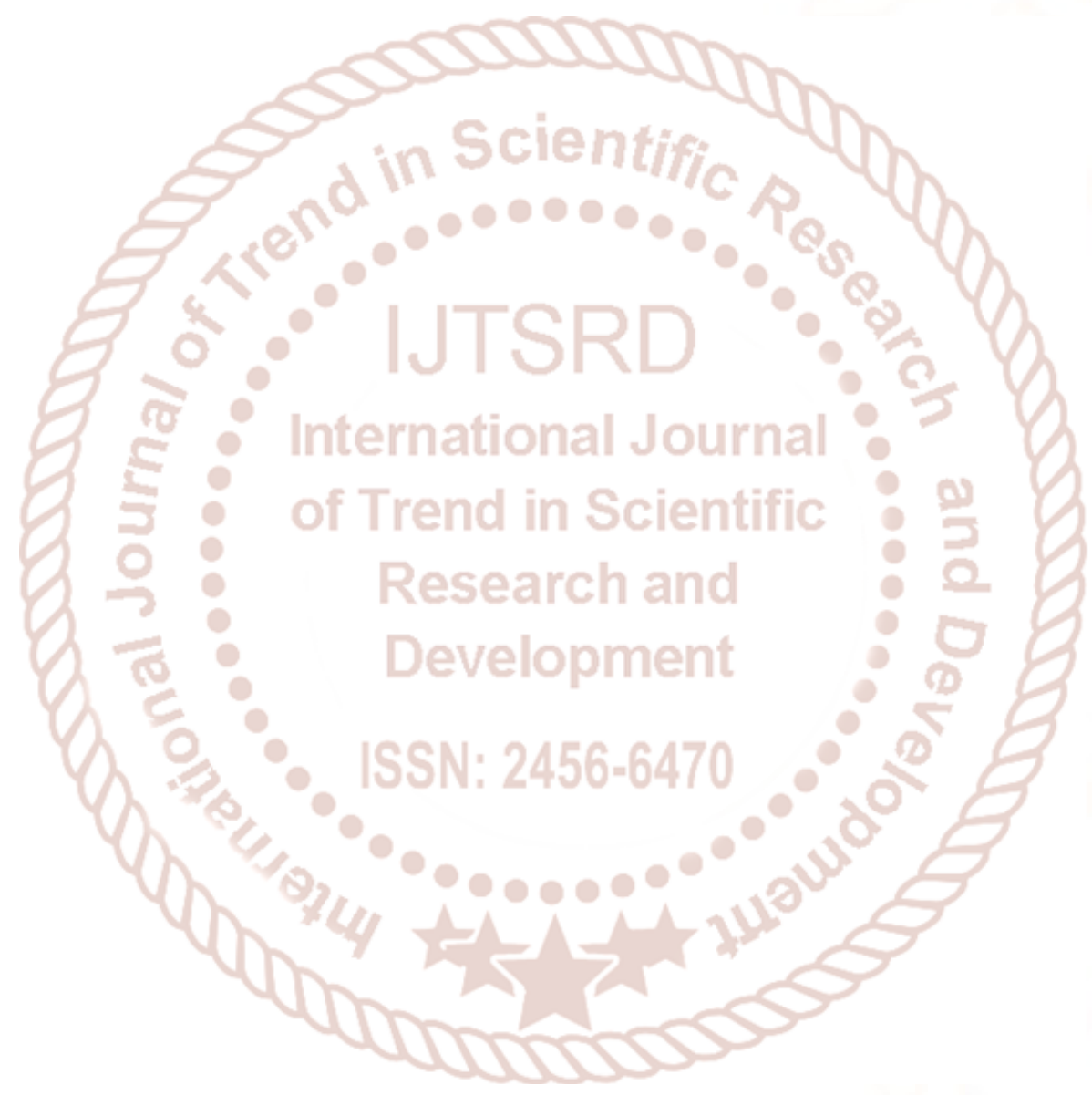

